\title{
ON THE PART OF WESTERN DISCOVERIES IN RESEARCH OF WELFARE STATE MODELS
}

\author{
ARVYDAS GUOGIS, \\ DAINIUS BERNOTAS \\ MYKOLO RIOMERIO UNIVERSITETAS
}

The problems of welfare models raise continuous concerns for both most of the residents of Western countries and their academic representatives, as well as a certain part of the Eastern European layers, especially the ones that are oriented towards a greater social justice and social protection. However, the works and the opinions on Western welfare models of sociologists, economists and political scientists are still insufficiently known in Lithuania. In this area, we are still lacking both historical and perspective analytical insights. This article will help to get better acquainted with the remarks of Esping-Andersen, Castles, Palier and some other Western researchers on the Western welfare models which were crystallized at the turn of the 21 st century.

\section{ANALYSIS OF THREE MAIN WELFARE STATE MODELS}

In the Western social science three main welfare state models have been established: (1) the most generous social model which is a universal one - the redistributory one - the social-democratic one which is most of all resembled in the Northern European countries, first of all, in Scandinavian countries; (2) a less generous one, the Bismarck model, i. e. the corporate one, the conservative one, which is best resembled by the Western European countries of the continental part; (3) the least generous being the Anglo-Saxon liberal one - the marginal model. These models are different in their dependence on the market conditions. The greatest market dependence is in the countries of the liberal-marginal model, where the qualification conditions 'to get social benefits and social services' are the most difficult ones. Dependence on the labour 
market is clearest in the countries of the second model, the corporate, the conservative one, where the benefits and the level of the services depend on the work experience and previous pay. The third model, i. e. the universal one, the redistributory - social-democratic one, which is based on the right of social citizenship and it means that it is sufficient to be a citizen of that country to be able to get a benefit or social services in case of poverty or emergency situation. This redistributory model is the most generous one not only from the quantitative point of view but it also is the most accessible one in terms of meeting the qualification conditions for obtaining benefits and receiving social services. All these three main models of Western social policy are called welfare models but most researchers admit that the institutional redistributory model - the social-democratic one - is the best developed one in social terms and the level of making people independent from the market is the greatest in it. This way in 1980, i. e. in the period when it was thriving, Sweden, as the most developed country of social democratic institutional - redistributory model according to its decommodification level outpaced the countries of corporate - conservative model, e. g. Germany, France or Belgium by 1.5 times or twofold, and the Anglo-Saxon countries by 2.5 or 3 times. Even though all the Western models are called social welfare models, the redistributory model of the Northern countries was certainly better than all others for many decades. And this can be stated even now when the Northern countries have refused some of the elements of the universal-redistributory part of their model (Bergh, 2010, p. 115, 117). Over the last decade, one can say, all the Western models have moved towards the liberal-marginal model, however, despite this the social indices of the Northern countries still remain better than those in the countries of the corporate-Bismarck model countries and much better than those in the Anglo-Saxon countries of liberal-marginal model (The Economist, 2012, Oct. 12). Only one thing is clear that Northern countries in the post-war period were on the global level alienated from and surpassed other countries according to social indices hence having refused more of their welfare states, they remain to be the leading countries. However, it seems that this refusal is not endless and one day dismantling of welfare states in Northern countries should stop. However, another situation is possible where the Northern countries can only stop when they have reached the level of the middle, corporate-conservative 
model. In such a controversial situation much depends on the capacity of the social democratic party policy of Northern countries in the nearest future - whether the period of their weakening is finished and whether adequate measures will be found to stop modern liberal capitalism. Most of the old social-democratic measures are not working anymore and they are not suitable anymore, but will new measures be found? The results of the Swedish social-democratic party of 2012-2014 allow initiating discussions about a partial recovery of social-democrats in Scandinavian countries. One should emphasize the fact that in 2013 the part of the public expenditure from GDP in Sweden still made 49 per cent, whereas back in 1993 the percentage was 67 per cent (The Economist, 2013, Feb. 2). However, in Lithuania this percentage reached 26 per cent in 2013 (Gylys, 21 January 2013). One should draw the attention to the fact that all this was happening during the governance of the social democrats lead coalition. The Lithuanian redistribution from GDP index was one of the smallest in the European Union, however, the members of the government led by Algirdas Butkevičius would not mention the fact. It is obvious that this kind of indicator alone is insufficient to be able to responsibly state about the unsuccessful development of welfare state in Lithuania. The aforementioned indicator of 'dependence on the market' (commodification) in Lithuania was in line with the indicators of the liberal countries as early as in 1997-2000 (Bernotas, Guogis, 2001, p. 311) even though there were no private pension funds and most of the privately provided social services then. Lately it has been difficult to collect data to calculate this indicator due to technical reasons, however, upon the arrival of private pension funds and once some of the municipalities passed the function of providing social services to private and nongovernmental organizations, it is very likely that the indicator of the 'dependence on the market' (commodification) should be significantly bigger. The level of commodification and privatization in other walks of public policy and public administration, during the implementation of the reforms was also increasing, it is especially noticeable in education, culture and health care sectors.

The European Union documentation has established that there is a number of overly interrelated different welfare models in Europe, therefore, it is difficult to create a single normative social model for it, however, one indirectly acknowledges that one should aim at creating such a model. 
During the past decades the move of all the models towards the liberalmarginal one in the area of modelling social policy allows to easier solve the question of the creation of a more unified European social model, however, one could state that there is no basis to create it in the direction of the liberal model since in most of Western European countries it still remains much more social that in the Anglo-Saxon Ireland and Great Britain. Furthermore, the welfare models of Ireland and Great Britain are more social than the liberal US social model. The corrections of the European social model may be brought by the economic problems of Southern Europe, however, Southern European countries are more inclined to influence the quantitative paragraphs of social costs, rather than qualitative amendments of the social structures. In this kind of situation the architects of the social systems of Eastern Europe and Lithuania must clearly state whether they support 'the social Europe' and refer to international documentation or whether they refuse to create a welfare state. Their attitude towards the problems of welfare state and individual models of welfare state should be made more concrete. Merely confirmation that Lithuania consciously chose the creation of a German-style Bismarck corporate model after the restoration of independence is not sufficient. For example, it is still not clear what is the attitude of the formers of the Lithuanian social policy model towards the welfare models of Northern countries and Southern Europe? There have been very few academic publications in Lithuania about the experience and argumentation of the social protection of individual Western countries, as to why some social models should be followed or rejected. On the contrary, the problems of welfare states in Western countries are still discussed in political and academic circles. Even though one still acknowledges that there have been some cardinal changes in social practice, politicians, administrators and academics often emphasize the historic importance of welfare state development. Therefore, it is surprising that Swedish social democrats have tried to formally patent their 'discovery' - a Northern model in their welfare state form (Norden, 6 August 2013). Since it is obvious that the Swedish social democrats of nearly entire $20^{\text {th }}$ century have stood out for the creation of their exceptional social-democratic model, for which it was characteristic to create the 'functional socialism' measures (it is interesting that even the rightist parties of Sweden approved them by consensus - and it was only possible to effectively create a corresponding 
welfare state only by mutual consensus of all the parties). Overall, any party of social democrats or leftists, as they declare to be, should refer to a corresponding ideology or practice. Even though in the Western world, e. g. in Portugal, there are some discrepancies between the name of social-democrat party and the policy they implement (the name of socialists of Portugal, the ideology and the practice are in line), but this is especially specific to Eastern European countries, and, first of all, Lithuania.

\section{CONTRIBUTION OF WESTERN RESEARCHERS TO THE PROBLEMS OF WELFARE STATES}

The pioneer of the social policy modelling should be considered to be the English sociologist Richard Titmuss whose works laid the foundation for singling out residual, industrial achievement performance and institutional-redistributive models at the beginning of 1970s. Titmuss based his research on qualitative analysis which allowed him to establish the most important trends of the development of social protection of the second half of the $20^{\text {th }}$ century (Titmuss, 1966).

The researcher that made the greatest breakthrough after Richard Titmuss in analyzing and assessing the models of Western social policy was Gøsta Esping - Andersen's work Three worlds of welfare capitalism, in which he substantiated the three-dimensional typology the socialdemocratic, corporatist-statist and liberal welfare models. This work had a great influence on the subsequent works of the researchers of welfare models (Castles, 1998).

Esping-Andersen emphasizes that his conception is based on the expanded approach towards a welfare state which is conditioned by the science of political economy. His conception comprises these most important characteristics of a welfare state: the relation of social rights, social stratification and public-private sectors (Esping-Andersen, 1990). The most important thing is that Esping-Andersen analyzes social rights as decommodification. Decommodification defines a person's possibility to live independently from the market. Esping-Andersen bases the indicators of decommodification on the criteria, such as: 'the norm of replacement' and 'the qualification conditions to receive the benefits of old-age, sickness and unemployed'. These indicators are aggregated 
into a common indicator enabling 'to divide the countries of the world into "three worlds". The Scandinavian countries are distinguished for the highest indicators, the Anglo-Saxon ones for the lowest ones and the continental countries of Europe fall somewhere between the two groups. The second important focus for Esping-Andersen is the influence of welfare states for stratification or the fact how it changes social relationships. The indicators of stratification are calculated by measuring testing of 'corporate statehood', asset, costs for private health care, the level of universality and equality of benefits. Welfare states are this way again divided into corporatist-statist, liberal and social-democratic models. The third object for Esping-Andersen is the relationship between the public and private sectors. According to this relationship between the state and the market, he singles out three 'types of pensions'.

However, Esping-Andersen's position has slightly changed in the past 10 years. In 1999 alongside decommodification he defined defamilialization as a result of welfare. Social risk and social risk management also take an important place in his work of 1999 (Esping-Andersen, 1999). Even though the analysis of social risk is less based on welfare models, defamilialization in Esping-Andersen's works is basically based on the same theoretic principles as decommodification. Its analysis ends by singling out of the liberal, corporatist-conservative and social-democratic models.

In the liberal model, social risk group persons appear due to poor market functioning (market failure) and welfare programmes are justified only in such a case if they are directed towards the obvious loss of market. The state limits welfare measures to the removal of bad risks by providing social support. The liberal model is supported by the market optimists who think that successful economic development will improve the functioning of the markets and will minimize market failures. Simultaneously, the likelihood of interfering in the functioning of the markets will be minimized.

The corporatist-statist (conservative model) singles out family as the most important element providing welfare. Social risks have influence on the family, and state and market measures for ensuring welfare are meant for removing family failures. The corporatist-statist welfare model is defined according to the gender and profession, and it is very closely related to the protection of the workplace. 
The social-democratic model is defined on the basis of the body of social risks. In the social-democratic model, the most important place belongs to the rights of human social development. This model is directed towards the expansion of economic participation. Welfare is marked by its nature to develop therefore it is universal and egalitarian and the state plays the main role in ensuring welfare.

Despite the importance of Esping-Andersen's works for attributing social policy models to specific types, it is impossible not to notice that his typology is based on the presumptions of the old passive social policy. First of all, it is based on the data of the golden age of welfare states, i. e. 1970-1980. Secondly, welfare measures in Esping-Andersen's works, especially the early ones, are based on the income support programmes, mostly in the areas of pension and social protection costs. These are passive programmes corresponding to Keynesian spirit of the post-war world. In contemporary world, this kind of attitude may be obsolete. At the centre of debate of social policy in the $21^{\text {st }}$ century there are preventive and active social protection measures. The significance of work market is especially emphasized. The boundaries between the economic and social rudiments, work and welfare are clearer. Welfare models in contemporary science are compared to the models of work market, the manufacturing models or various forms of capitalism. However, this kind of new modelling also has significant shortcomings. First of all, it compares the areas that are too different. The inclusion of the active work market problems into the modelling of social policy is closest to social policy problems and, from the methodological point of view, it is the most valid one. Active labour market policy is the most important element of activization and supply of the national governments' policy. It is an especially important component in the policy of OECD, the World Bank and the European Union policy. Active labour market policy is directly related to the ideology of workfare, the Schumpeter post-national welfare model and the ideology of the Third Way, which was substantiated by the famous English sociologist Anthony Giddens (Giddens, 2000, 2001). Looking at the results of the Active work market policy, from the quantitative point of view, Robinson (2000, p. 13-26) and Sinfield (2001) criticize the simplified dichotomy of active/passive as a politically engaged and misleading. In the broadest sense, such measures are prescribed to active policy that improve the involvement of non active and unemployed 
persons into the work market, the investments into the development of competences and in the broadest sense they comprise the functioning of the work market.

One should note that the costs of Active labour market policy (ALMP) are smaller than they are usually considered to be (Martin, 1998). The costs of ALMP have slightly increased in most of the countries. Martin notices that in OECD countries the ALMP costs have increased from 0.7 per cent in 1985 until 0.9 per cent in 1996. The average increase in EU countries in 1990s was 30 per cent. Even though the data of 1975 and 1980 was formed on a different basis than subsequent data, one can deduce that the ALMP costs in the United Kingdom and the US in 1990s decreased, and they significantly increased in Germany, France, Sweden and Denmark.

At the beginning of the $21^{\text {st }}$ century the costs for the active labour market policy were continuously increasing mostly in Western European countries. In the meantime, Eastern Europe, Eastern Asia and Latin America were lagging behind in this area. However, lately these countries have also realized the importance of active labour market policy (ALMP).

Esping-Andersen only partly included ALMP into the typology he suggested. This was done by Janoski in his work of 1994 by providing Sweden, Germany and the US as the most typical examples of the socialdemocratic, conservative and liberal models (Janoski, 1994). Janoski also notes that the costs for the active labour market policy are significant in Sweden, average in Germany and small in the US. Therefore, Janoski draws a conclusion in support of Esping-Andersen's typology that the unemployment political economy perfectly fits into his typology of welfare models.

Gallie and Paugam suggest four unemployment welfare models that are based on the extent, level of compensation and ALMP costs (Gallie, Paugam, 2000). They note that ALMP costs are not significant in Southern European countries. They are small in the liberal models of the United Kingdom and Ireland and much greater in the models of France, Germany, the Netherlands and Belgium that are based on the labour market. ALMP costs are significant in the universal model of Denmark and Sweden. This kind of typology is very similar to 'the four worlds of welfare capitalism', where the Southern European model (Arts, Gelissen, 2002, p. 137-158) or 'the families of four nations' that are singled out by 
Castles and Mitchell (1993) and Castles (1998) are added to the three models of Esping-Andersen. However, this kind of division has some flaws since in 1996 the expenditure on ALMP of the United Kingdom was smaller as compared to Spain and Portugal, whereas Ireland spent more than any of the four countries that are work market oriented. Lødemel and Trickey in their work of 2000 suggest a more versatile division (Lødemel, Trickey, 2000). Having analyzed the data of 1999 of seven countries they note that two liberal countries had small ALMP expenditure (the United Kingdom) and average expenditure (the US), two conservative countries had insignificant expenditure (Germany) and average expenditure (France), two social-democratic countries had insignificant costs (Denmark) and significant costs (Norway). The Netherlands, as a country lying somewhere between the social-democratic and corporatist-statist (conservative) model, had insignificant ALMP costs. The attempts to include ALMP into the typology of welfare models has significant shortcomings. Acknowledging that ALMP is important for ensuring welfare, it is evident that there is a lack of agreement among scientists whether ALMP helps to single out the models of capitalism, manufacturing and labour market. It is not completely clear how all of this should fit into the typology of welfare state models. However, Powell and Barrientos, having used various quantitative methods, arrive at the conclusion in their article that was published in 2004 that the ALMP problem basically is not in contradiction to the typology of three models suggested by Gøsta Esping-Andersen (2004, p.101).

The subsequent research in the area of welfare states the emphasis is put also on other criteria describing social welfare state models (for example, the extent of expenditure of the public sector, the indicator of income inequality, the level of female employment, etc.). However, despite the variety of variables describing social models that were used in subsequent works, most of them, as in the case of Esping-Andersen's work, can be prescribed to one of the two main groups of criteria: the public policy and the overall social-economical situation of residents. Some of the authors suggest including the third group - that of civic participation criteria which has influence on the state public policy and its results - into the subsequent research of comparative social policy. As an example of such work, one could provide Sébastien Saint-Arnaud and Paul Bernard's research on the welfare regimes in the advanced 
societies, in which the authors suggest evaluating three groups of variables making the social model: public policy, social situations and civic participation (Saint-Arnaud, Bernard, 2003). Their research, which is based on the results of a hierarchical cluster analysis and homogeneity/ differences of welfare regimes, has revealed four different regimes of welfare states: Latin, comprising Spain, Italy, Greece and Portugal, conservative, comprising such countries as Austria, Germany and France, social-democratic, comprising Finland, Sweden, Denmark and Norway, and the liberal one, comprising the UK, Australia, New Zealand and the US. However, the first author to punctuate Southern-European welfare model is regarded Italian researcher Mauricio Ferrera, who comprised South-European model as a corporatist-conservative-clientelistic, where clientelism is a distinctive feature from the corporatist - conservative European states northwards (Ferrera, 1996).

In the subsequent research, a hierarchical cluster analysis method was used to find out the suitability of Esping-Andersen's welfare state model typology for the post-Communist Central and Eastern European countries. This research has additionally confirmed the existence of the fact of the controversial post-communist social model and denied the attempt to incorporate all the post-communist Central and Eastern European countries into the typology of three-four traditional European social models (Fenger, 2007). Beside the proposed extended typology of European social models, in which a group of the new EU member states welfare regimes is singled out, this research is also significant in that it marks the differentiation of the development of the social models in the post-communist countries.

One of the most famous recent researchers of welfare states could be considered the French author Bruno Palier, whose scheme of interpretation is based on the dualistic conception of welfare state. In the book he edited in 2010, A Long Good Bye to Bismarck? he states that in the continental Western Europe the society is as if divided into those within the welfare system and those outside the welfare system, since part of the society are subject to the state, professional and private insurance schemes, and part of it are subject to in-work poverty ensuring income or that of unemployed, they are subject to only minimum social benefits or services (Palier, 2010, p. 383-385). 


\section{CONCLUSIONS}

Western social science, by providing the typology of Western welfare state models, has mostly referred to the models of three capitalist worlds: liberal, corporatist-statist (conservative) and social-democratic that were proposed by the Danish researcher Gøsta Esping-Andersen.

In terms of social protection and work market one can single out the same three main Western welfare state models. Some authors complement them with the fourth one - the Southern European model, even though a more extended modelling is possible, including the postcommunist Central and Eastern European model.

Despite Gøsta Esping-Andersen's special merits in making the typology of welfare states, on can sense the paradigm of passive welfare policy in his early works, which becomes obsolete in the conditions of globalization. His subsequent works and other researcher's works put emphasis on the importance of active social policy and active labour market policy, which is proved by statistical data.

Bruno Palier, alongside with a number of other researchers, emphasizes some essential changes of the conservative-Bismarck's model during the recent decade. The society of the continental Western Europe as if divides itself into those within the welfare system and those outside the welfare system, since part of the society are subject to state, professional and private insurance schemes, and part of it are subject to the jobs ensuring in-work poverty income level, or unemployed that are only subject to minimum social benefits or services.

\section{REFERENCES}

1. Arts, W., Gelissen, J. (2002) Three Worlds of Welfare Capitalism or More? Journal of European Social Policy, 2 (12): 137-158.

2. Bernotas, D., Guogis, A. (2001) The Lithuanian Social Policy Model. Journal of Baltic Studies, XXXII (3): 308-313.

3. Castles, F. (1998) Comparative Public Policy. Cheltenham: Edward Elgar.

4. Castles, F., Mitchell, D. (1993) Three Worlds of Welfare Capitalism or Four In: Castles, F. (ed.). Families of Nations. Brookfield: Dartmouth.

5. Esping-Andersen, G. (1999) Social Foundations of Post-industrial Economies. Oxford: Oxford University Press.

6. Esping-Andersen, G. (1990) The Three Worlds of Welfare Capitalism. Cambridge: Polity Press, Chapters 2, 3, 4. 
7. Fenger, H. J. M. (2007) Welfare Regimes in Central and Eastern Europe: Incorporating Post-communist Countries in a Welfare Regime Typology. Contemporary Issues and Ideas in Social Sciences, August.

8. Ferrera, M. (1966) The Southern Model of Welfare in Social Europe. Journal of European Social Policy, 6: 17-37.

9. Gallie, D., Paugam, S. (2000) The Experience of Unemployment in Europe: The Debate. In: D. Gallie, S. Paugam (eds.). Welfare Regimes and the Experience of Unemployment in Europe. Oxford: Oxford University Press.

10. Gylys, P. (2013) Pagaliau mes ES pirmi!!! www.delfi.lt, 2013.01.21 [seen 2807 2013]. Online access: http://www.delfi.lt/news/ringas/politics/pgylyspagaliau-mes-es-pirmi.d?id $=60483579$

11. Giddens, A. (2000) The Third Way and Its Critics. Cambridge: Polity Press.

12. Giddens, A. (ed.) (2001) The Global Third Way Debate. Cambridge: Polity Press.

13. Janoski, T. (1994) Direct State Intervention in the Labor Market: The Explanation of Active Labour Market Policy from 1950 to 1988 in Social democratic, Conservative and Liberal Regimes. In: T. Janoski, A. M. Hicks (eds.). The Comparative Political Economy of the Welfare State. Cambridge: Cambridge University Press.

14. Lødemel, I., Trickey, H. (2000) An Offer You Can't Refuse: Workfare in International Perspective. Bristol: Policy Press.

15. Martin, J. P. (1998) What Works Among Active Labour Market Policies: Evidence from OECD Countries' Experiences. Labour Market and Social Policy Occasional Papers 35. Paris: OECD.

16. Norden. "Nordic model" patent dispute attracts international attention. (2011) [seen 201308 06]. Online access: http://www.norden.org/en/news-andevents/news/nordic-model-patent-dispute-attracts-international-attention

17. Palier, B. (ed.) (2010) A Long Goodbye to Bismarck? Amsterdam: Amsterdam University Press.

18. Powell, M., Barrientos, A. (2004) Welfare Regimes and the Welfare Mix. European Journal of Political Research, 1 (43), January: 101.

19. Robinson, P. (2000) Active Labour Market Policies: A Case of Evidence-based Policy-making? Oxford Review of Economic Policy, 16: 13-26.

20. Saint-Arnaud, S., Bernard, P. (2003) Convergence or Resilience? A Hierarchical Cluster Analysis of the Welfare Regimes in Advanced Countries. Current Sociology, 5 (51), September: 499-527.

21. Sinfield, A. (2001) Benefits and Research in the Labour Market. Paper Presented to ESF Conference on Labour Market Change, Unemployment, Welfare and Citizenship in Europe, Helsinki, 20-25 April.

22. Sweden. The New Model. A Bit More Unequal, a Lot More Efficient. (2012) The Economist, October 13.

23. Titmuss, R. (1966) Essays on The Welfare State. London: Unwin University Books.

24. Wooldridge, A. (2013) The Nordic countries are reinventing their model of capitalism. The Economist, February 2. 


\section{SANTRAUKA}

\section{APIE KAI KURIUOS VAKARU MOKSLO ATRADIMUS GEROVÉS VALSTYBIŲ MODELIŲ TYRIMO SRITYJE}

Gerovės valstybių modeliai kelia pastovų tiek Vakarų šalių gyventojų ir juos reprezentuojančių tyrëju, tiek stebėtojų Rytų Europoje susidomèjimą - ypač tų, kurie tiria socialinès apsaugos ir socialinio teisingumo problemas. Vis dèlto Lietuvoje Vakaru sociologu, politologu ir ekonomistų darbai ir įžvalgos gerovés valstybių modeliavimo srityje yra dar per mažai žinomi. Trūksta tiek istorinès, tiek perspektyvų analizès. Šis straipsnis leidžia geriau susipažinti su požiūriais, teorijomis ir tipologijomis, kurios šia tema buvo išvystytos turtingose kapitalistinès demokratijos šalyse. Straipsnyje atskleidžiama tokių gerovès valstybių tipologijos klasikų kaipTitmusas ir Esping-Andersenas darbų reikšmė. Po to pereinama prie vèlesnių autorių, tokių kaip Castlesas, Ferrera, Palieris ir kitu, indèlio, praplètusio ir praturtinusio gerovès valstybių modelių tematika, kuri pilnai susiformavo XX ir XXI amžių sandūroje. Nẻra abejonės, kad, tyrinejjant šią sritị, vis dar i̇manoma rasti nauju vertinimo kriteriju ir pasiremti naujais statistiniais duomenimis, tiek istoriniu, tiek lyginamuoju požiūriu. 
